\title{
Comparative Study of Intralesional Triamcinolone Acetonide and Hyaluronidase vs Placental Extract in 60 Cases of Oral Submucous Fibrosis
}

\author{
Sudhir M Naik, Mohan K Appaji, S Ravishankara, MK Goutham, Nonthombam Pinky Devi \\ Annapurna S Mushannavar, Sarika S Naik
}

\begin{abstract}
Background: Oral submucous fibrosis (OSMF) is a common premalignant condition caused by chewing arecanut, betel quid and gutkha with tobacco. Its medical treatment is not yet fully standardized, although the optimal doses of its medical treatment is in the form of triamcinolone acetonide combined with hyaluronidase or intralesional placental extract.
\end{abstract}

Objectives: We compared the efficacy of intralesional triamcinolone acetonide combined with hyaluronidase in group A vs placental extract in group $B$.

Design: Comparative case series analysis series study with random allocation of 60 patients equally into two groups.

Materials and methods: Patients of OSMF (60) were randomly allocated into two groups $A$ and B. Group A $(n=30)$ patients received combination of triamcinolone acetonide $(10 \mathrm{mg} / \mathrm{ml})+$ hyaluronidase $(1,500 \mathrm{IU})$ at weekly intervals for 8 weeks. G roup $\mathrm{B}(\mathrm{n}=30)$ patients received $2 \mathrm{ml}$ of placentrex injection intralesionally at weekly interval for 8 weeks. Treatment outcome was evaluated on the basis of improvement in trismus, oral mucosal pattern and reduction in burning sensation.

Results: Trismus improvements in group A with combination of triamcinolone acetonide + hyaluronidase were significantly better to that in group B where placentrex was used. No significant difference in results in the two groups were observed as far as improvement in oral mucosal pattern and burning sensation were compared in the two groups.

Conclusion: Combination of triamcinolone acetonide and hyaluronidase intralesionally is more effective than placental extract intralesionally in treatment of OSMF. But placental extract injections are cost-effective. No side effects were seen in both study groups.

Keywords: Oral submucous fibrosis, Triamcinolone acetonide, Placentrex injection, Hyaluronidase injection, Trismus.

How to cite this article: Naik SM, Appaji MK, Ravishankara S, Goutham MK, Devi NP, Mushannavar AS, Naik SS. Comparative Study of Intralesional Triamcinolone Acetonide and Hyaluronidase vs Placental Extract in 60 Cases of Oral Submucous Fibrosis. Int J Head Neck Surg 2012;3(2):59-65.

Source of support: Nil

Conflict of interest: None declared

\section{INTRODUCTION}

Oral submucous fibrosis (OSMF) is a chronic insidious premalignant condition of the oral mucosa. ${ }^{1-3}$ It is an insidious, chronic change in fibroelasticity, characterized by a burning sensation in the oral cavity, blanching and stiffening of the oral mucosa and oropharynx and trismus. ${ }^{4}$
Schwartz coined the term atrophica idiopathica mucosa oris to describe an oral fibrosing disease as he discovered in five Indian women from K enya. ${ }^{5}$ J oshi subsequently termed the condition OSM F. ${ }^{5}$

It is clinically and histopathologically characterized diffusely blanched mucosa, presence of fibrous bands, depapillated tongue, erosions in the mucosa, where the patients chiefly complains of burning mouth and inability to take spicy food. ${ }^{1,2}$ J uxtaepithelial inflammatory reaction, fibroelastic changes in the lamina propria and epithelial atrophy leading to stiffness of oral mucosa, trismus and inability to eat. ${ }^{1,2}$

It is a precancerous condition common in the Indian subcontinent. ${ }^{6}$ The incidence varies from 0.2 to $0.5 \%$ in India with a higher percentage being found in southern areas. ${ }^{6}$ The exact etiology is still obscure, but many factors, such as betel nut, tobacco, smoking, pan masala and chillies, have been thought to be contributory. If untreated, the risk of malignant change in advanced cases of OSMF is relatively high. ${ }^{6}$

The clinical diagnosis is done on the basis of (a) difficulty to take hot and spicy foods, (b) difficulty in opening mouth, (c) inability to protrude the tongue, (d) blanching of oral mucosa, (e) reduced elasticity and mobility of tissues (f) presence of fibrous bands on palpation. ${ }^{6}$

Treatment includes intralesional injections of placental extract which act as biogenic stimulant and use is based on the tissue therapy method. ${ }^{6}$ A lso used are intralesional corticosteroid injections with hyaluronidase. ${ }^{7}$

\section{MATERIALS AND METHODS}

This is a comparative case series analysis study of $60 \mathrm{OSM} F$ patients managed under two different treatment schedules in Department of ENT Head and Neck surgery done during the study period of 56 months from M arch 2007 to N ovember 2011. Institutional ethical committee scrutinized the study and clearance was obtained.

Sixty patients, both males and females, were randomly allocated into two groups of 30 each, i.e. group $A(n=30)$ and group $B(n=30)$.

All patients in the present study are arecanut, betel quid, gutkha and tobacco chewers in various combinations (Table 1). 


\begin{tabular}{llccccccc}
\hline \multicolumn{8}{c}{ Table 1: Improvement of mouth opening during the course of treatment } \\
\hline & 0 week & 1st week & 2nd week & 3rd week & 4th week & 6th week & 8th week & $\begin{array}{l}\text { p-value at 8th week } \\
\text { b/w groups A and B }\end{array}$ \\
\hline Group A & 16.266 & 18.6 & 22.4 & 26.2 & 28.8 & 34.2 & 35.9 & 0.000 \\
Group B & 15.83 & 19.2 & 24.2 & 26.4 & 29.4 & 32.1 & 33.8 & - \\
\hline
\end{tabular}

Diagnosis of OSM F were done on clinical criteria and no biopsy was done. Lesions suggestive of other diseases clinically were excluded from the study. SPSS 17 program were used to analyze the data.

The selected patients included both males and females of all age groups and socioeconomic status. Y oungest was 11-year-old boy and oldest 52-year-old man. There were 47 males and 13 females in our study. The average age was 27.4 years in group $A$ and 28.2 years in group B. M ost of the patients were young manual laborers who easily had access to gutkha (flavored arecanut with tobacco) cheaply (Graph 1).

A part from the baseline investigations mouth opening, color and burning sensation of the oral mucosa were recorded in groups $A$ and $B$ before and after infiltration of triamcinol one acetonide $(10 \mathrm{mg} / \mathrm{ml})+$ hyal uroni dase $(1500$ $\mathrm{IU}$ ) in group $\mathrm{A}$ and $2 \mathrm{ml}$ of placentrex injection in group $\mathrm{B}$. Intralesional injections were given in the soft palate and in the fibrous bands formed anterior to anterior pillars (at multiple sites bilaterally).

The mouth opening was recorded using a graduated vernier gauge to measure the distance between the upper and lower central incisal edges at maximal unaided mouth opening (IID-interincisal distance; Fig. 1). IID of $40 \mathrm{~mm}$ and above was considered as normal mouth opening score (grade 0 , no trismus), 30 to $39 \mathrm{~mm}$ (grade 1, trismus), 20 to $29 \mathrm{~mm}$ (grade 2, trismus), 10 to $19 \mathrm{~mm}$ (grade 3, trismus) and 0 to $9 \mathrm{~mm}$ (grade 4 , trismus).

The color of oral mucosa was assessed in natural light and scored as normal pink (0), red or deep pink (1), pale

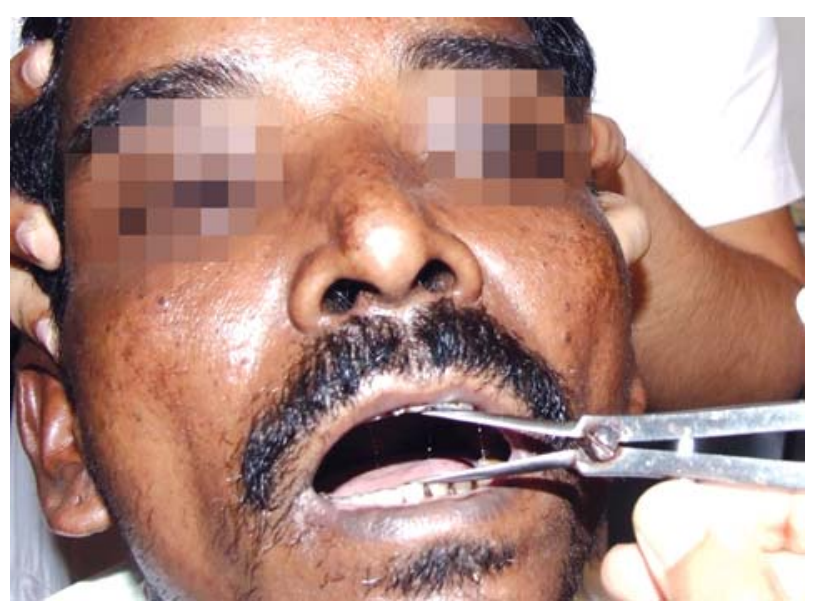

Fig. 1: Trismus measured using calipers

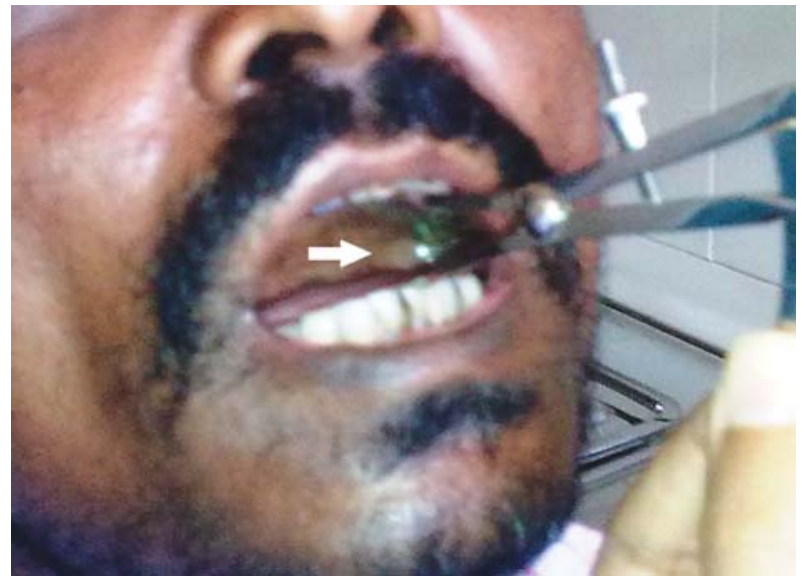

Fig. 2: Blanched oral mucosa seen

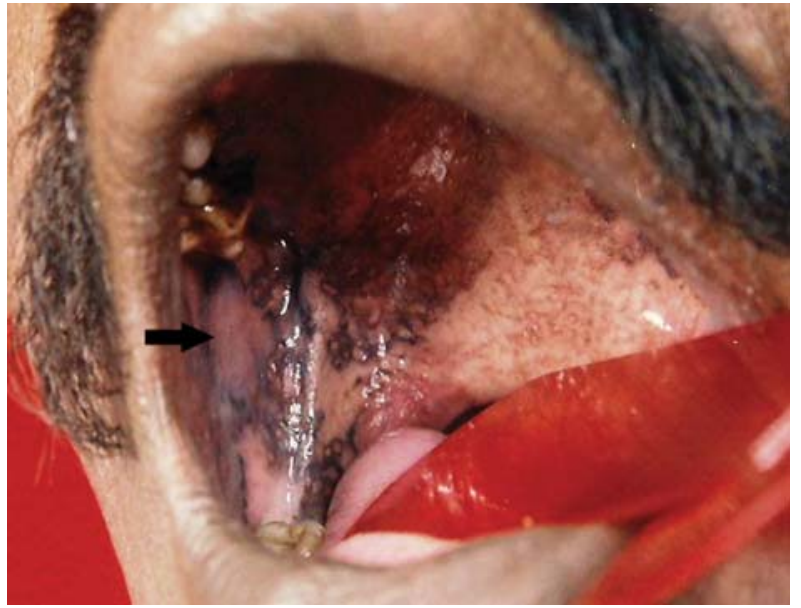

Fig. 3: Fibrosed mucosa with tobacco staining seen

white (2) and blanched white (3) (Figs 2 and 3). Increased burning sensation of mouth to chilies or spicy foods is graded

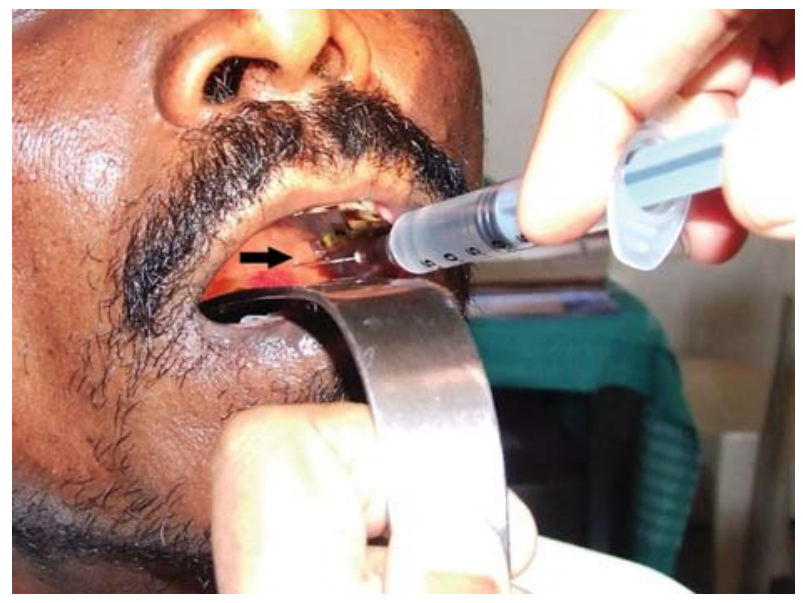

Fig. 4: Intralesional injections being given 
according to the severity of burning as; no burning sensation (0), minimal burning sensation (1), moderate burning sensation (2) and severe burning sensation (3). The infiltrations were done submucosally $1 \mathrm{ml}$ on each side of the pal ate and pillars. The infil trations were done every week in groups $A$ and $B$ and the three parameters IID, color of oral mucosa and burning sensation noted (Fig. 4).

\section{RESULTS}

A Il the 60 patients were in the grade 3 trismus at the time of diagnosis. The average IID improved from 16.266 to

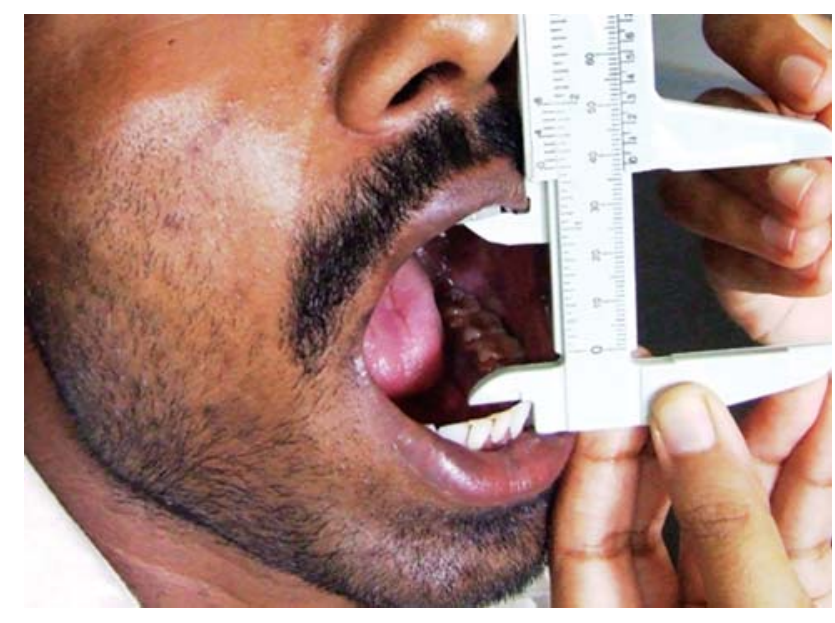

Fig. 5: IID measured after 8 weeks of successful treatment
$35.9 \mathrm{~mm}$ in group $A$ and from 15.83 to $33.8 \mathrm{~mm}$ in group $B$ after 8 weeks of treatment (Fig. 5 and Table 2).

A significant improvement were seen in both the groups in all the three parameters.

The difference in mouth opening score at 8 weeks were significant with group A patients showing better results compared to group B (Graph 2).

The difference of scores in improvement of burning sensation and oral mucosal pattern at 8th week were not significant when groups $A$ and $B$ were compared.

All the group A and B patients had relief from grade 3 to grade 1 trismus after 8 weeks of treatment.

Significant reduction in burning sensation was seen from the 2nd week itself in both groups (Table 3 and Graph 3).

Color of the oral mucosa improved from blanched white to normal pink in most of the cases (Table 4 and Graph 4).

$N$ o reactions to the injections or complications were seen in both study groups. All the patients were given multivitamins, iron folic acid tablets and antioxidants after 8 weeks. No analgesics were given to the patients as $26 \mathrm{gm}$ needle was used during the procedure which was virtually painless. Pearson's Chi-square test was used to test significance of the results in the two groups and the values were tabulated using Levene's test for equality of variances (Tables 5 to 7 ).

Overall intralesional triamacinolone acetonide and hyaluronidase is better than placental extract in treating

Table 2: Burning sensation in the oral cavity improved during the course of treatment

\begin{tabular}{lllllllll}
\hline & 0 week & 1st week & 2nd week & 3rd week & 4th week & 6th week & 8th week & $\begin{array}{l}\text { p-value at 8th week } \\
\text { b/w groups A and B }\end{array}$ \\
\hline Group A & 2.36 & 2.20 & 2.03 & 1.70 & 1.46 & 1.26 & 0.96 & 0.167 \\
Group B & 2.56 & 2.36 & 2.16 & 1.93 & 1.60 & 1.23 & 0.86 & - \\
\hline
\end{tabular}

Table 3: Improvement in the color of the oral mucosa during the course of treatment

\begin{tabular}{lllllllll}
\hline & 0 week & 1st week & 2nd week & 3rd week & 4th week & 6th week & 8th week & $\begin{array}{l}\text { p-value at 8th week } \\
\text { b/w groups A and B }\end{array}$ \\
\hline Group A & 2.733 & 2.466 & 2.266 & 2.033 & 1.466 & 1.133 & 0.833 & 0.960 \\
Group B & 2.633 & 2.366 & 2.233 & 2.066 & 1.533 & 1.100 & 0.866 & - \\
\hline
\end{tabular}

\begin{tabular}{|c|c|c|c|c|c|c|}
\hline Group & & & Mean & $\mathrm{N}$ & Std. deviation & Std. error mean \\
\hline 1.00 & $\begin{array}{l}\text { Pair } 1 \\
\text { Pair } 2 \\
\text { Pair } 3\end{array}$ & $\begin{array}{l}\text { @ 0_week } \\
\text { @ 8th_week } \\
\text { @ 0_Cweek } \\
\text { @ 8th_Cweek } \\
\text { @ 0_Bweek } \\
\text { @ 8th_Bweek }\end{array}$ & $\begin{array}{r}16.2667 \\
35.9000 \\
2.3667 \\
0.9667 \\
2.7333 \\
0.8333\end{array}$ & $\begin{array}{l}30 \\
30 \\
30 \\
30 \\
30 \\
30\end{array}$ & $\begin{array}{l}2.03306 \\
1.93605 \\
0.49013 \\
0.18257 \\
0.44978 \\
0.37905\end{array}$ & $\begin{array}{l}0.37118 \\
0.35347 \\
0.08949 \\
0.03333 \\
0.08212 \\
0.06920\end{array}$ \\
\hline 2.00 & $\begin{array}{l}\text { Pair } 1 \\
\text { Pair } 2 \\
\text { Pair } 3\end{array}$ & $\begin{array}{l}\text { @ 0_week } \\
\text { @ 8th_week } \\
\text { @ 0_Cweek } \\
\text { @ 8th_Cweek } \\
\text { @ 0_Bweek } \\
\text { @ 8th_Bweek }\end{array}$ & $\begin{array}{r}15.8333 \\
33.8000 \\
2.5667 \\
0.8667 \\
2.6333 \\
0.8667\end{array}$ & $\begin{array}{l}30 \\
30 \\
30 \\
30 \\
30 \\
30\end{array}$ & $\begin{array}{l}1.93129 \\
1.51771 \\
0.50401 \\
0.34575 \\
0.49013 \\
0.34575\end{array}$ & $\begin{array}{l}0.35260 \\
0.27709 \\
0.09202 \\
0.06312 \\
0.08949 \\
0.06312\end{array}$ \\
\hline
\end{tabular}


Table 5: Paired sample's correlations

\begin{tabular}{llllrr}
\hline Group & & & N & Correlation & Sig. \\
\hline \multirow{2}{*}{1.00} & Pair 1 & @ 0_week \& @ 8th_week & 30 & 0.121 & 0.525 \\
& Pair 2 & @ 0_Cweek \& @ 8th_Cweek & 30 & -0.244 & 0.194 \\
& Pair 3 & @ 0_Bweek \& @ 8th_Bweek & 30 & -0.270 & 0.150 \\
2.00 & Pair 1 & @ 0_week \& @ 8th_week & 30 & 0.059 & 0.758 \\
& Pair 2 & @ 0_Cweek \& @ 8th_Cweek & 30 & -0.145 & 0.444 \\
& Pair 3 & @ 0_Bweek \& @ 8th_Bweek & 30 & 0.312 & 0.093 \\
\hline
\end{tabular}

Table 6: Group statistics

\begin{tabular}{llllcc}
\hline & Group & N & Mean & Std. deviation & Std. error mean \\
\hline @ 0_week & 1.00 & 30 & 16.2667 & 2.03306 & 0.37118 \\
@ 8th_week & 2.00 & 30 & 15.8333 & 1.93129 & 0.35260 \\
@ 0_Cweek & 1.00 & 30 & 35.9000 & 1.93605 & 0.35347 \\
@ 8th_Cweek & 2.00 & 30 & 33.8000 & 1.51771 & 0.27709 \\
& 1.00 & 30 & 2.3667 & 0.49013 & 0.08949 \\
@ 0_Bweek & 1.00 & 30 & 2.5667 & 0.50401 & 0.09202 \\
@ 8th_Bweek & 1.00 & 30 & 0.9667 & 0.18257 & 0.03333 \\
& 1.00 & 30 & 0.8667 & 0.66868 & 0.06312 \\
\hline
\end{tabular}

Table 7: Levene's test for equality of variances

\begin{tabular}{|c|c|c|c|c|c|c|c|c|c|c|}
\hline & \multirow{3}{*}{$\begin{array}{l}\text { Levene's test for } \\
\text { equality of variances }\end{array}$} & \multicolumn{9}{|c|}{ t-test for equality of means } \\
\hline & & $\mathrm{F}$ & Sig & $\mathrm{t}$ & df & \multirow[t]{2}{*}{$\begin{array}{c}\text { Sig. } \\
\text { (2-tailed) }\end{array}$} & \multirow{2}{*}{$\begin{array}{c}\text { Mean } \\
\text { difference } \\
\text { Upper }\end{array}$} & \multirow{2}{*}{$\begin{array}{l}\text { Std. error } \\
\text { difference } \\
\text { Lower }\end{array}$} & \multicolumn{2}{|c|}{$\begin{array}{c}\text { 95\% confidence } \\
\text { e } \begin{array}{c}\text { interval of the } \\
\text { difference }\end{array}\end{array}$} \\
\hline & & Lower & Upper & Lower & Upper & & & & Upper & Lower \\
\hline \multirow[t]{2}{*}{ @0_week } & $\begin{array}{l}\text { Equal variances } \\
\text { assumed }\end{array}$ & 0.015 & 0.901 & 0.846 & 58 & 0.401 & 0.43333 & 0.51196 & -0.59147 & 1.45814 \\
\hline & $\begin{array}{l}\text { Equal variances } \\
\text { not assumed }\end{array}$ & - & - & 0.846 & 57.848 & 0.401 & 0.43333 & 0.51196 & -0.59153 & 1.45820 \\
\hline \multirow[t]{2}{*}{ @ 8th_week } & $\begin{array}{l}\text { Equal variances } \\
\text { assumed }\end{array}$ & 1.272 & 0.264 & 4.676 & 58 & 0.000 & 2.10000 & 0.44914 & 1.20095 & 2.99905 \\
\hline & $\begin{array}{l}\text { Equal variances } \\
\text { not assumed }\end{array}$ & - & - & 4.676 & 54.872 & 0.000 & 2.10000 & 0.44914 & 1.19986 & 3.00014 \\
\hline \multirow[t]{2}{*}{ @ 0_Cweek } & $\begin{array}{l}\text { Equal variances } \\
\text { assumed }\end{array}$ & 0.988 & 0.324 & -1.558 & 58 & 0.125 & -0.20000 & 0.12836 & -0.45693 & 0.05693 \\
\hline & $\begin{array}{l}\text { Equal variances } \\
\text { not assumed }\end{array}$ & - & - & -1.558 & 57.955 & 0.125 & -0.20000 & 0.12836 & -0.45694 & 0.05694 \\
\hline \multirow[t]{2}{*}{ @ 8th_Cweek } & $\begin{array}{l}\text { Equal variances } \\
\text { assumed }\end{array}$ & 8.930 & 0.004 & 1.401 & 58 & 0.167 & 0.10000 & 0.07138 & -0.04289 & 0.24289 \\
\hline & $\begin{array}{l}\text { Equal variances } \\
\text { not assumed }\end{array}$ & - & - & 1.401 & 44.006 & 0.168 & 0.10000 & 0.07138 & -0.04387 & 0.24387 \\
\hline \multirow[t]{2}{*}{ @ 0_Bweek } & $\begin{array}{l}\text { Equal variances } \\
\text { assumed }\end{array}$ & 0.374 & 0.543 & 0.000 & 58 & 1.000 & 0.00000 & 0.15137 & -0.30299 & 0.30299 \\
\hline & $\begin{array}{l}\text { Equal variances } \\
\text { not assumed }\end{array}$ & - & - & 0.000 & 53.182 & 1.000 & 0.00000 & 0.15137 & -0.30358 & 0.30358 \\
\hline \multirow[t]{2}{*}{ @ 8th_Bweek } & $\begin{array}{l}\text { Equal variances } \\
\text { assumed }\end{array}$ & 0.010 & 0.920 & -0.051 & 57 & 0.960 & -0.00460 & 0.09070 & -0.18623 & 0.17703 \\
\hline & $\begin{array}{l}\text { Equal variances } \\
\text { not assumed }\end{array}$ & - & - & -0.051 & 56.861 & 0.960 & -0.00460 & 0.09073 & -0.18628 & 0.17709 \\
\hline
\end{tabular}


Comparative Study of Intralesional Triamcinolone Acetonide and Hyaluronidase vs Placental Extract in 60 Cases

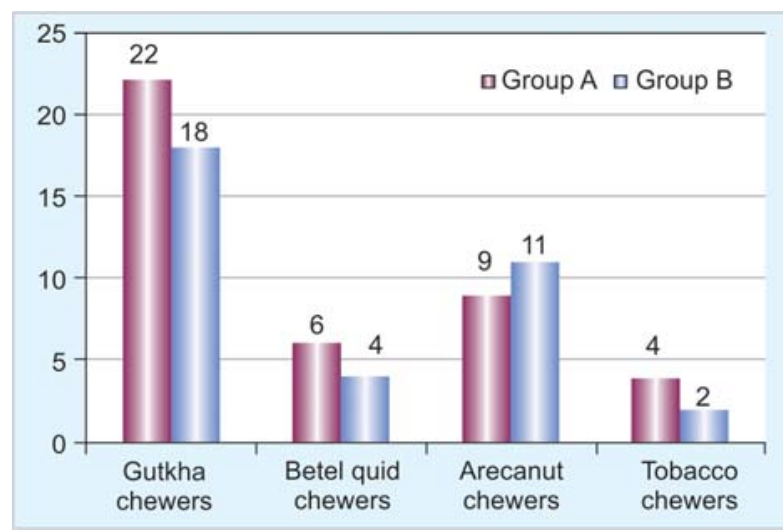

Graph 1: Habits seen in patients in both groups

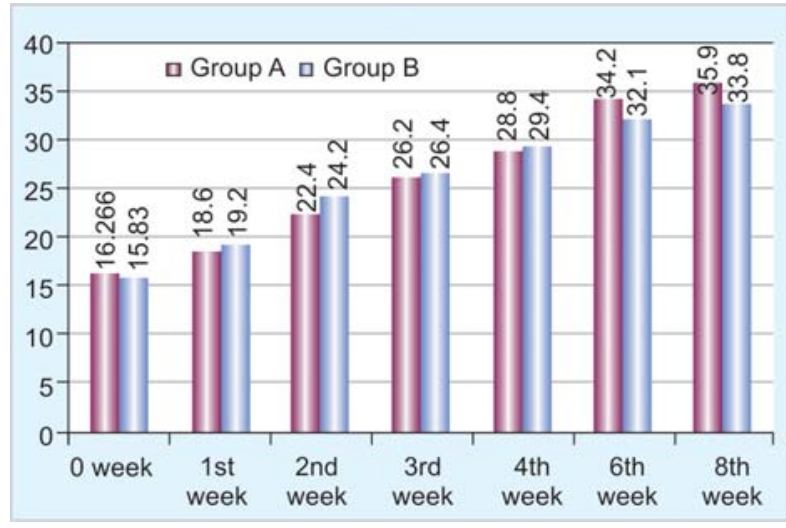

Graph 2: Improvement of mouth opening during the course of treatment

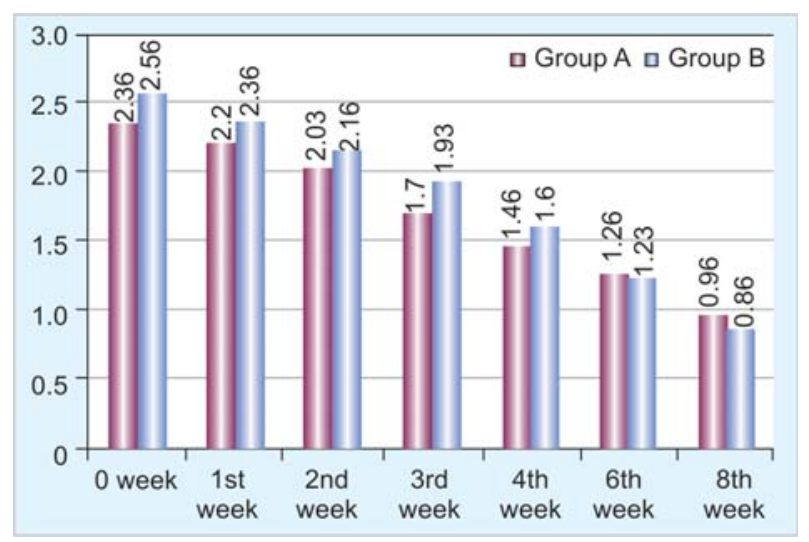

Graph 3: Burning sensation in the oral cavity improved during the course of treatment

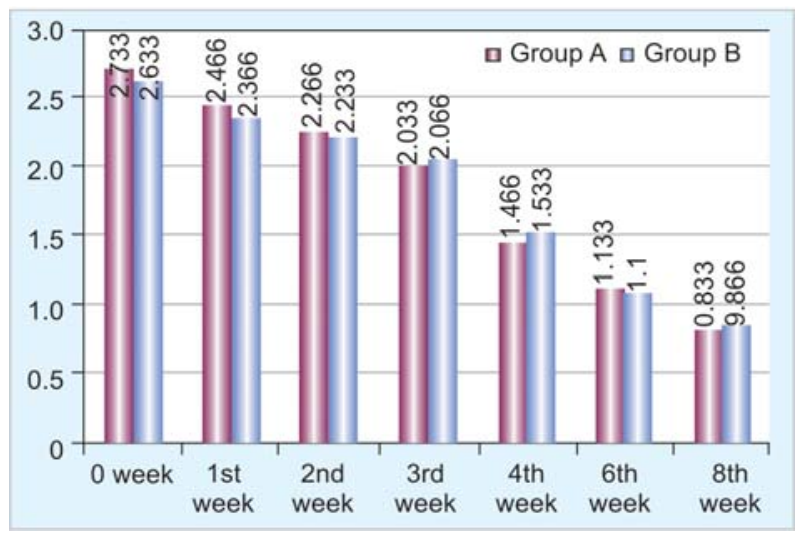

Graph 4: Improvement in the color of the oral mucosa during the course of treatment trismus of OSM F but give equal results when parameters of burning sensation and improvement in oral mucosal color is concerned.

\section{DISCUSSION}

Oral submucous fibrosis is a widely preval ent oral mucosal lesion in Indian population and considering its premalignant potential and severe clinical manifestations many studies are done by many authors regarding various aspects of this condition such as etiology pathogenesis and treatment. Etiology and pathogenesis of OSM $\mathrm{F}$ is obscure. ${ }^{8,9} \mathrm{~A}$ recoline of Areca catechu is mostly attributed as the causative factors in addition to pan and tobacco in different combinations. ${ }^{8,9}$

A recoline, an active alkaloid found in betel nuts, stimulates fibroblasts to increase production of collagen by $150 \% .{ }^{10}$ A recoline was found to elevate the mRNA and protein expression of cystatin $C$, a nonglycosylated basic protein consistently up regulated in a variety of fibrotic diseases, in a dose-dependent manner in persons with OSM F. ${ }^{11}$

A recoline is an inhibitor of metalloproteinases and a stimulator of tissue inhibitor of metalloproteinases, thus decreasing the overall breakdown of tissue collagen. ${ }^{12}$ Keratinocyte growth factor-1, insulin-like growth factor-1 and IL -6 expression, which have all been implicated in tissue fibrogenesis, were also significantly up regulated in persons with OSM F due to areca quid chewing and arecoline may be responsible for their enhanced expression. ${ }^{13,14}$ Flavanoid, catechin and tannin in betel nuts cause collagen fibers to cross-link, making them less susceptible to collagenase degradation. ${ }^{15}$ This results in increased fibrosis by causing both increased collagen production and decreased collagen breakdown. ${ }^{16}$

OSM F remains active even after cessation of the chewing habit, suggesting that components of the arecanut initiate OSMF and then affect gene expression in the fibroblasts, which then produce greater amounts of normal collagen. ${ }^{17}$ Chewing areca quid may also activate NF-kappa-B expression, thereby stimulating collagen fibroblasts and leading to further fibrosis. ${ }^{18}$

A recanuts have a high copper content and chewing areca-nuts for 5 to 30 minutes significantly increases soluble copper levels in oral fluids. This increased level of soluble copper supports the hypothesis that copper acts as an initiating factor in OSM F by stimulating fibrogenesis through up regulation of copper-dependent lysyl oxidase activity. ${ }^{19}$ Other factors attributed are immunological, nutritional, allergy, viral and candidal infections. ${ }^{19}$ 
The disease initially presents as burning sensation in oral cavity. It is clinically divided into three stages. ${ }^{20}$ In stage 1 there is stomatitis, erythematous mucosa, vesicles, mucosal ulcers, melanotic mucosal pigmentation and mucosal petechiae. ${ }^{21,22}$ In stage 2 , fibrosis occurs in ruptured vesicles and ulcers when they heal. There is blanching of oral mucosa. ${ }^{21,22} V$ ertical and circular palpable fibrotic bands are seen in buccal mucosa. ${ }^{21,22}$ Specific findings include trismus, stiff and small tongue, blanched and leathery floor of mouth, fibrotic and depigmented gingiva, rubbery soft palate with decreased mobility, blanched and atrophic tonsils, shrunken band-like uvula and sinking of cheek not commensurate with age or nutritional status. ${ }^{21,22}$ In stage 3, there are sequelae in the form of leukoplakia in about $25 \%$ of cases, speech and hearing deficits because of involvement of tongue, palate and eustachian tubes. ${ }^{21,22}$

Treatment protocol for OSM F is not standardized. M ost important aspect of medical treatment is quitting chewing betel quid, arecanut, other local irritants, spicy and hot food, alcohol and smoking. ${ }^{2,3}$ The various modalities of treatments include: Intralesional corticosteroid injections with hyaluronidase, intralesional injections of placental extract, systemic administration of corticosteroids, lycopene, ${ }^{23}$ pentoxifyline therapy ${ }^{24}$ and surgical excision of fibrous bands is being tried with various degrees of success.

Placental extract contains growth factors and antiinflammatory agents ${ }^{6}$ and also antiplatelet activity. ${ }^{6}$ The action of placenta extract is essentially biogenic stimulation and use is based on the tissue therapy method. ${ }^{6}$ A ccording to this theory when animal and vegetable tissues are severed from the parent body and exposed to unfavorable conditions, but not mortal to their existence, undergo biogenic readjustment leading to development of substance in the state of their survival to ensure their vitality biogenic stimulators. ${ }^{6}$ Such tissues or their extract when implanted or injected into the body after resistance of pathogenic factors stimulates metabolic or regenerative process thereby favoring recovery. ${ }^{6}$

Triamcinolone acetonide suppresses immune system by reducing activity and volume of Iymphatic system. ${ }^{7,16} \mathrm{It}$ heals inflammatory mucosal lesions that are responsive to steroids. Decreases inflammation by suppressing the migration of polymorphonuclear leukocytes and by reversing capillary permeability. ${ }^{7,16}$ It is a better corticosteroid for intralesional injection as it has better local potency, longer duration of action and lesser systemic absorption. . $^{76}$

Hyaluronidase is an enzyme which reduces the viscosity of ground substance, thus making the tissues more permeable to injected corticosteroid triamcinolone acetonide. ${ }^{7,16}$ It stimulates hydrolysis of hyaluronic acid, one of the chief ingredients of tissue cement, which offers resistance to diffusion of liquids through tissues. ${ }^{7,16}$ It facilitates distribution and absorption of locally injected substances. ${ }^{7,16}$ It also promotes resorption of excess fluids and extravasated blood in the tissues. ${ }^{7,16}$

Sinha et al in his 36 cases study has inferred that injection hydrocortisone is five times more effective than placentrex in qual doses. ${ }^{25}$

Kaushal et al used $2 \mathrm{mg}$ collagenase in $1 \mathrm{ml}$ distilled water with good symptomatic relief. ${ }^{26} \mathrm{~K}$ akar et al in theirs 96 cases study using dexamethasone $4 \mathrm{mg}$, hyaluronidase $1,500 \mathrm{IU}$, hyaluronidase 1,500 IU + dexamethasone $4 \mathrm{mg}$ and $2 \mathrm{ml}$ placental extract in four separate groups found hyaluronidase 1,500 IU + dexamethasone $4 \mathrm{mg}$ more effective than the rest. ${ }^{27}$ According to study by Deepak Gupta et al chymotrypsin, hyaluronidase and dexamethasone are more effective than placentrex. ${ }^{8}$ Chaturvedi et al treated 103 patients with combination of $1 \mathrm{ml}$ hydrocortisone and 1,500 IU hyaluronidase with good results. ${ }^{28}$

Borle et al found in his 326 cases study lesser relapses with oral formulation of vitamin A 50,000 IU + $\mathrm{FeSO}_{4} 200$ $\mathrm{mg}+$ beclomethasone drops/6th hourly for 3 weeks than compared to injection triamcinolone + hyaluronidase. ${ }^{29}$ $K$ atharia et al noted drastic improvement in symptoms and fibrous bands with $2 \mathrm{ml}$ placentrex in his 22 case study. ${ }^{6}$ Lai et al in their study over 10 years concluded that dexamethasone $4 \mathrm{mg}$ + hyaluronidase 1,500 IU weekly for 20 weeks better than surgical treatment. ${ }^{30}$

\section{CONCLUSION}

Intralesional infiltrations with placental extract and triamcinolone with hyaluronidase are equally effective in treating trismus of OSM F. No difference in treatment efficacy was seen in placental extract group or with triamcinolone with hyaluronidase group. But placental extract injections are cost-effective. No side effects were seen in both study groups.

\section{REFERENCES}

1. Pindborg J J, Zacharia J. Frequency of oral submucous fibrosis among 100 South Indian with oral cancer. Bull WHO 1965;32:750-53.

2. Pindborg, Chawla, Srivatsava, Gupta. Clinical aspects of OSM F. A cta Odont Scand 1964;22:679-81.

3. Hayes PA. OSM F in a 4 years child. Oral Surg 1985;59: 475-78.

4. A darsh Chopra, PS Sethi, Jagroop Singh, Dimple. Oral submucous fibrosis (OSM F). Indian J D ermatol V enereol L eprol 2000;66(5):255-56.

5. Joshi SG. Submucous fibrosis of palate and pillars. Ind J Otolaryngol 1953;4:1-4. 
Comparative Study of Intralesional Triamcinolone Acetonide and Hyaluronidase vs Placental Extract in 60 Cases

6. Katharia SK, Singh SP, K ulshreshtha VK. The effects of placenta extract in management of oral submucous fibrosis. Indian J Pharmacol 1992;24:181-83.

7. M angal Singh, N iranjan HS, M ehrotra R, Sharma D, Gupta SC. Efficacy of hydrocortisone acetate/hyaluronidase vs triamcinolone acetonide/hyaluronidase in the treatment of OSM F: Indian J M ed Res 2010 M ay;131:665-69.

8. Gupta DS, Gupta MK, Golhar BL. Oral submucous fibrosis clinical study and management by physiofibrolysis (M W B). J Ind Dent A sso 1980;52:375-78.

9. Kumar K, Srivastava CM , M athur R M , Pradhan R. The effects of collagenase and oral submucous fibrosis. J Ind Dent A sso 1980;52:243-46.

10. Canniff JP, Harvey W. The etiology of oral submucous fibrosis: The stimulation of collagen synthesis by extracts of areca nut. Int J Oral Surg 1981;10:163-67.

11. Chung-Hung $T$, Shun-Fa $Y, Y$ u-Chao $C$. The upregulation of cystatin C in oral submucous fibrosis. Oral Oncol 2007;43(7): 680-85.

12. Chang Y C, Y ang SF, Tai KW, Chou M Y, H sieh Y S. Increased tissue inhibitor of metalloproteinase-1 expression and inhibition of gelatinase A activity in buccal mucosal fibroblasts by arecoline as possible mechanisms for oral submucous fibrosis. Oral Oncol 2002 Feb;38(2):195-200.

13. Tsai $\mathrm{CH}, \mathrm{Y}$ ang $\mathrm{SF}, \mathrm{Chen} \mathrm{YJ}$, et al. The upregulation of insulinlike growth factor-1 in oral submucous fibrosis. O ral O ncol 2005 Oct; 41(9):940-46.

14. Tsai $\mathrm{CH}, \mathrm{Y}$ ang $\mathrm{SF}, \mathrm{Chen} \mathrm{YJ}$, et al. Regulation of interleukin- 6 expression by arecoline in human buccal mucosal fibroblasts is related to intracellular glutathione levels. Oral Dis 2004 Nov;10(6):360-64.

15. Harvey W, Scutt A, M eghji S, Canniff JP. Stimulation of human buccal mucosa fibroblasts in vitro by betel-nut alkaloids. A rch Oral Biol 1986;31(1):45-49.

16. A ziz SR. Oral submucous fibrosis: A n unusual disease. J NJ Dent Assoc. Spring 1997;68(2):17-19.

17. van W yk CW, Stander I, Padayachee A, Grobler-RabieA F. The areca nut chewing habit and oral squamous cell carcinoma in South A frican-Indians. A retrospectivestudy. S A fr M ed J 1993 Jun;83(6):425-29.

18. Ni WF, Tsai CH, Y ang SF, Chang Y C. Elevated expression of NF-kappa B in oral submucous fibrosis - Evidence for N F-kappa $B$ induction by safrole in human buccal mucosal fibroblasts. Oral Oncol 2006 Sep;21.

19. Trivedy CR, W arnakulasuriya $K A$, Peters $T$ ] , et al. R aised tissue copper levels in oral submucous fibrosis. J Oral Pathol Med 2000 J ul;29(6):241-48.

20. Pindborg J J. Oral submucous fibrosis: A review. 4. A nn A cad M ed Surg 1989;18:603-07.

21. K hanna S. Histological changes in palatal and paratubal muscles in oral submucous fibrosis. M S thesis, U niversity of Allahabad; 1999.

22. Chaturvedi R. To study the Eustachian tube function in patients of oral submucousfibrosis. M S thesis, U niversity of Allahabad; 2003.

23. Kumar A, Bagewadi A, Keluskar V, Singh M. Efficacy of Iycopene in the management of OSM F. Or Sur Or Med 2007;103;207-13.
24. Rajendran R, Rani V, Shaikh S. Pentoxyphyline therapy; a new adjunct in the treatment of OSM F. Indian J Dent Res 2006:17:190-98.

25. Sinha SN, Jain PK. Intraoral injection of hydrocortisone and placental extract in oral submucous fibrosis. Indian J Otolaryngol 1978; 30:103.

26. K aushal K umar. Collagenase: Preparation, properties, action and uses: A review of literature. J Indian Dent Assoc 1980;52: 353-54.

27. Kakar PK, Puri RK, V enkatachalam VP. Oral submucous fibrosis treatment with hyalase. J Laryngol Otol 1985;99: 57-59.

28. Chaturvedi VN, Sharma AK, M arathe NG. Intraoral injection of hydrocortisone and hyaluronidase in oral submucous fibrosis. Indian Prac 1990; 575-80.

29. B orle R M , B orle SR. M anagement of oral submucous fibrosis: A conservative approach. J Oral Maxillofac Surg 1991;49: 788-91.

30. Lai DR, Chen HR, Lin LM, Huang $Y L$, T sai CC. Clinical evaluation of different treatment methods for oral submucous fibrosis. A 10-year experience with 150 cases. J Oral Pathol Med 1995;24:402-06.

\section{ABOUT THE AUTHORS}

\section{Sudhir M Naik (Corresponding Author)}

A ssociate Professor, D epartment of ENT and Head and N eck Surgery KV G M edical College and Hospital, K urunjibag, Sullia, K arnataka India, Phone: 919916807109, e-mail: sud223@gmail.com

\section{Mohan K Appaji}

Professor and Head, Department of ENT and Head and Neck Surgery K V G M edical Collegeand H ospital, K urunjibag, Sullia, K arnataka, India

\section{S Ravishankara}

A ssociate Professor, D epartment of ENT and Head and N eck Surgery K V G M edical Collegeand H ospital, K urunji ibag, Sullia, Karnataka, India

\section{MK Goutham}

SeniorR esident, D epartment of EN T and H ead and N eck Surgery, K V G M edical College and Hospital, K urunjibag, Sullia, Karnataka, India

\section{Nonthombam Pinky Devi}

SeniorR esident, D epartment of EN T and H ead and N eck Surgery, K V G M edical College and Hospital, K urunjibag, Sullia, Karnataka, India

\section{Annapurna S Mushannavar}

SeniorR esident, D epartment of EN T and H ead and N eck Surgery, K V G M edical College and Hospital, K urunjibag, Sullia, Karnataka, India

\section{Sarika S Naik}

Senior Resident, Department of Anesthesia and Critical Care Narayana Hrudayalaya, Bengaluru, K arnataka, India 